\title{
Catalyst, Co-ion and the Media Effect on the Oscillatory Behavior of Resorcinol in the BZ Reaction
}

\author{
Nadeem B. Ganaie* and G. M. Peerzada \\ Department of Chemistry, University of Kashmir, 190006 Srinagar, Jammu and Kashmir, India
}

\begin{abstract}
O estudo diz respeito ao comportamento oscilatório de resorcinol como substrato orgânico na reação de Belousov-Zhabotinsky (BZ) em presença de diferentes íons metálicos como catalisadores no meio aquoso ácido. Verifica-se que íons $\mathrm{Mn}^{2+}$ como catalisador são mais reativos que íons $\mathrm{Fe}^{2+}$. Variando o meio aquoso ácido observa-se que as espécies protonadas são mais facilmente formadas em ácido sulfúrico do que o substrato orgânico (resorcinol) e devido a isto um número maior de oscilações é observado neste meio. Além disso, foi estudado o efeito de diferentes ânions como acetato, carbonato e sulfato, associados com o mesmo íon metálico $\left(\mathrm{Mn}^{2+}\right)$ como catalisador, sobre o comportamento oscilatório do sistema. Um modo misto das oscilações é observado mudando a concentração de ácido sulfúrico.
\end{abstract}

The study pertains to the oscillatory behavior of resorcinol as organic substrate in BelousovZhabotinsky (BZ) reaction in presence of different metal ions as catalysts in aqueous acid media. It is found that $\mathrm{Mn}^{2+}$ ion as catalyst is most reactive in comparison to ferroin $\left(\mathrm{Fe}^{2+}\right)$. On varying the aqueous acid media, it is observed that protonated species with respect to organic substrate (resorcinol) is more easily formed in aqueous sulfuric acid, owing to which maximum number of oscillations are observed in this medium. Moreover, the effect of different anions like acetate, carbonate and sulfate associated with the same metal ion $\left(\mathrm{Mn}^{2+}\right)$ as catalyst on the oscillatory behavior of the reaction system was also studied. Mixed mode oscillations are seen while changing concentration of aqueous sulfuric acid medium.

Keywords: BZ reaction, mixed mode oscillations, catalyst, autocatalytic oxidation

\section{Introduction}

Oscillations can arise in a macroscopic medium if the system is sufficiently far from the state of thermodynamic equilibrium. ${ }^{1}$ Oscillating chemical reactions have been known for about three hundred years, but these were mainly heterogeneous reactions. In the beginning of the 20th century, two excellent examples of heterogeneous oscillating reactions had been discovered: the so-called "iron nerve", the periodic dissolution of an iron wire in nitric acid, and the "mercury heart", the oscillatory decomposition of hydrogen peroxide on the surface of metallic mercury. ${ }^{2,3}$ The Belousov-Zhabotinsky (BZ) reaction is a family of oscillating chemical reactions. ${ }^{4}$ During these reactions, transition-metal ions catalyze oxidation of various, usually organic, reductants by bromic acid in aqueous acid solution. Most BZ reactions are homogeneous. The $\mathrm{BZ}$ reaction makes it possible to observe development

\footnotetext{
*e-mail: nadeemganaie@ rediffmail.com
}

of complex patterns in time and space by naked eye on a very convenient human time scale of dozens of seconds and space scale of several millimeters. The BZ reaction can generate up to several thousand oscillatory cycles in a closed system, which permits studying chemical waves and patterns without constant replenishment of reactants. ${ }^{5-8}$ An oscillatory cycle can be qualitatively described in the following way. Suppose that a sufficiently high $\mathrm{Ce}^{4+}$ concentration is present in the system. Then, $\mathrm{Br}^{-}$will be produced rapidly, and its concentration will also be high. As a result, autocatalytic oxidation of $\mathrm{Ce}^{3+}$ is completely inhibited, and the $\left[\mathrm{Ce}^{4+}\right]$ decreases due to its reduction by organic substrate and its bromoderivative. The $\left[\mathrm{Br}^{-}\right]$ decreases along with that of $\left[\mathrm{Ce}^{4+}\right]$. When $\left[\mathrm{Ce}^{4+}\right]$ reaches its lower threshold, the bromide ion concentration drops abruptly. The rapid autocatalytic oxidation starts and raises $\left[\mathrm{Ce}^{4+}\right]$. When $\left[\mathrm{Ce}^{4+}\right]$ reaches its higher threshold, $\left[\mathrm{Br}^{-}\right]$ increases sharply and inhibits the autocatalytic oxidation of $\mathrm{Ce}^{3+}$. The cycle then repeats. The reader can check this description by tracing a limit cycle generated by the 
Oregonator model ${ }^{9}$ which shows that $\mathrm{HOBr}$ was the final product of the oxidation of $\mathrm{Ce}^{3+}$ to $\mathrm{Ce}^{4+}$ by $\mathrm{HBrO}_{3}$. Vavilin put forward the simplest mechanism of the autocatalytic oxidation of $\mathrm{Ce}^{3+}$ or ferroin by bromate and its inhibition by bromide ion. ${ }^{10}$

$$
\begin{aligned}
& \mathrm{HBrO}_{3}+\mathrm{HBrO}_{2} \rightarrow 2 \mathrm{BrO}_{2}{ }^{-}+\mathrm{H}_{2} \mathrm{O} \\
& \mathrm{H}^{+}+\mathrm{BrO}_{2}+\mathrm{Fe}(\text { phen })_{3}^{2+} \rightarrow \mathrm{Fe}(\text { phen })_{3}^{3+}+\mathrm{HBrO}_{2} \\
& \mathrm{HBrO}_{2}+\mathrm{H}^{+}+\mathrm{Br}^{-} \rightarrow 2 \mathrm{HOBr}
\end{aligned}
$$

Field, Koros and Noyes $(\mathrm{FKN})^{11}$ presented a detailed and systematic mechanism for the BZ oscillations including the reactions discussed above as well as the additional reactions given below that are necessary for oscillations to occur.

$$
\begin{aligned}
& 2 \mathrm{H}^{+}+\mathrm{BrO}_{3}^{-}+\mathrm{Br}^{-} \rightarrow \mathrm{HBrO}_{2}+\mathrm{HOBr} \\
& \mathrm{HBrO}_{2}+\mathrm{HBrO}_{2} \rightarrow \mathrm{HOBr}+\mathrm{BrO}_{3}^{-}+\mathrm{H}^{+}
\end{aligned}
$$

They performed systematic and detailed thermodynamic and kinetic analysis of the basic quasi-elementary reactions involved in the BZ reaction and suggested a detailed mechanism of the reaction responsible for oscillations. To overcome some problems associated with the above mechanism Gyorgyi, Turanyi and Field (GTF) ${ }^{12,13}$ proposed a mechanism, which incorporated all the experimental information available at that time. According to this mechanism, the organic free radicals which play an important role undergo disproportionation on reacting with each other, rather than getting recombined. The Marburg-Budapest-Missoula (MBM) ${ }^{14}$ model includes both negative feedback loops (bromous acid-bromide ion Oregonator type and bromine dioxide-organic free radical type feedback) deals only with cerium catalyzed system. A detailed study of the BZ reaction with aliphatic compounds like oxalic acid, ${ }^{15,16}$ malonic acid, ${ }^{17,18}$ gallic acid, ${ }^{19}$ citric acid, ${ }^{4}$ glucose,${ }^{20}$ pyrocatechol ${ }^{21}$ and ketones viz., cyclohexanone $e^{22}$ and acetone ${ }^{23}$ in wide range of concentrations of the substrates have been reported. Although it is reported that oscillations exhibit remarkable change with increasing or decreasing concentrations of reaction medium, e.g., increasing or decreasing the concentration of sulfuric acid results in increase or decrease in the formation of the protonated substrate. The varying concentration of reaction medium affects the induction period $\left(t_{\text {in }}\right)$, time period $\left(t_{\mathrm{p}}\right)$ as well as the rate of reaction. Surely temperature is one of the environmental factors that have a pronounced effect on bromate driven oscillators. Temperature dependence for a variety of catalyzed and uncatalyzed bromate driven oscillators have been characterized. ${ }^{24-29}$
In the present study, oscillatory behavior of the $\mathrm{BZ}$ reaction comprising of resorcinol ${ }^{30}\left(\mathrm{C}_{6} \mathrm{H}_{4}(\mathrm{OH})_{2}\right)$ as the organic substrate, inorganic bromate as the oxidant and metal ions like $\mathrm{Mn}^{2+}, \mathrm{Ce}^{3+}, \mathrm{Ce}^{4+}$ and $\mathrm{Fe}^{2+}$ as catalysts was studied in different aqueous acid media. Resorcinol was chosen as the organic oscillator because of its two phenolic $\mathrm{OH}$ groups, having some similarity with biomolecules. ${ }^{31}$ Thus this type of study can serve as a prototype example in understanding the oscillatory behavior in biological systems. ${ }^{32-35}$ Moreover, it exhibited dynamic behavior in aqueous acid medium over a wide range of concentrations in the $\mathrm{BZ}$ reaction systems. The main objectives of this investigation are: (i) To compare the catalytic role of metal ions like $\mathrm{Mn}(\mathrm{II}), \mathrm{Ce}(\mathrm{III}), \mathrm{Ce}(\mathrm{IV})$ and $\mathrm{Fe}$ (II) on resorcinol based BZ reaction. (ii) To monitor the effect of co-ions like sulfate, acetate and carbonate as salts of the same metal (catalyst), i.e., Mn(II). (iii) To study the effect of different aqueous acid media like sulfuric acid, nitric acid, orthophosphoric acid and perchloric acid on the oscillatory behavior of $\mathrm{BZ}$ reaction.

\section{Experimental}

All reagents used were either analytical grade chemicals or else of high purity. The reagents used were Resorcinol 99\% (Himedia, AR), Potassium bromate 99\% (Merck), Manganese(II)sulfate monohydrate (s.d.fine), Nitric acid, Orthophosphoric acid, Perchloric acid, Sulfuric acid (Merck, LR), Manganese(II)acetate, Manganese(II) carbonate, Ferroin, Cerium(III)nitrate tetrahydrate (s.d.fine) and Cerium(IV)sulfate (Merck).

The ion analyzer (ELICO LI-126) having $\mathrm{pH}$ as well as $\mathrm{mV}$ option was calibrated in ORP mode with the standard solutions, using Platinum electrode as the indicator and Calomel (SCE) as the reference electrodes. The equipment was hooked to two half cells, one containing any of the reaction systems under investigation into which Platinum electrode was dipped as indicator electrode. The another half cell was filled with $2.5 \times 10^{-4} \mathrm{~mol} \mathrm{~L}^{-1}$ solution of Potassium chloride and the calomel electrode was dipped into it as reference electrode. The two half cells were connected through salt bridge filled with potassium nitrate and thermostated at a temperature of $30^{\circ} \pm 0.1^{\circ} \mathrm{C}$ in a Siskin Julabo water bath. All the solutions used in the reaction systems were first kept under thermostatic conditions at desired temperature for about ten minutes in order to attain the temperature of the bath.

\section{Results and Discussion}

The data with respect to induction period $\left(\mathrm{t}_{\mathrm{in}} / \mathrm{s}\right)$ and oscillation time period $\left(\mathrm{t}_{\mathrm{p}} / \mathrm{s}\right)$ for the different metal ions 
as catalysts is reported in Table 1 and the potential $(\mathrm{mV})$ versus time (s) plot of the same is given as Figure 1. The $t_{\text {in }}$ and $t_{p}$ values of the metal ions indicate that $\mathrm{Mn}(\mathrm{II})$ ion reacts faster to form $\mathrm{HBrO}_{2}$ and $\mathrm{Mn}(\mathrm{III})$ as the oxidized species. On the other hand, Fe(II) reacts very slowly to give $\mathrm{HBrO}_{2}$ and $\mathrm{Fe}(\mathrm{III})$ as its oxidized form. The frequency and amplitude are in good agreement with the generalization about their reactivity. Amplitude of the oscillation depicts the change in the $[\mathrm{Mn}(\mathrm{III})] /[\mathrm{Mn}(\mathrm{II})]$ during each cycle, which in turn gives us the concentration of the intermediate species generated in the processes A, B, C. This is further explained from Figure 2, wherein the slow increase (Process A) involves reaction of metal ion and the substrate to oxidize the metal ion, the sharp increase (Process B) is because of the reaction of the catalyst and the bromoderivatives of the substrate. From these two steps the oxidation of catalyst takes place which causes a negative feedback in the reaction and sharp decrease (Process C) takes place involving the formation of the $\mathrm{Mn}$ (II) from the reaction of $\mathrm{Mn}$ (III) with bromoderivatives of the substrate(resorcinol). On the basis of the FKN mechanism, Field and Noyes ${ }^{36}$ have developed a mathematical model of the $\mathrm{BZ}$ reaction named Oregonator. It includes an additional reaction of $\mathrm{HBrO}_{3}$ with $\mathrm{Br}^{-}$that produces $\mathrm{HBrO}_{2}$, and disproportionation of $\mathrm{HBrO}_{2}$. Tyson ${ }^{37,38}$ reduced Oregonator to two-variable versions with the fast variable as $\left[\mathrm{Br}^{-}\right]$or $\left[\mathrm{HBrO}_{2}\right]$, and the slow variable as $\left[\mathrm{Ce}^{4+}\right]$. The only irreplaceable initial reagent is the oxidant bromate. The Tyson ${ }^{39}$ expression for velocity of the wave is

Velocity $\left.=2\left(\mathrm{kD}^{+} \mathrm{H}^{+}\right]\left[\mathrm{BrO}_{3}^{-}\right]\right)^{1 / 2}$

Where $\mathrm{k}$ is the rate constant for the formation of $\mathrm{HBrO}_{2}$ and $\mathrm{D}$ is the diffusion coefficient for $\mathrm{HBrO}_{2}$, being equal to $2 \times 10^{-5} \mathrm{~cm}^{2} \mathrm{~s}^{-1}$. From the above expression, velocity is directly proportional to the concentration of bromate and on the basis of reactions (1) and (2), it is evident that the formation of $\mathrm{HBrO}_{2}$ directly depends on the $\left[\mathrm{BrO}_{3}^{-}\right]$. The order of the reactivity of different metal ions is

$\mathrm{Mn}(\mathrm{II})>\mathrm{Ce}(\mathrm{IV})>\mathrm{Ce}(\mathrm{III})>\mathrm{Fe}(\mathrm{II})$

From this trend it is also observed that use of the oxidized form of the catalyst like $\mathrm{Ce}^{4+}$ in place of $\mathrm{Ce}^{3+}$ enhances its reactivity in the reaction system.

The acidic medium in $\mathrm{BZ}$ reaction gives rise to protonation of the substrate like resorcinol in the present system to protonated substrate:

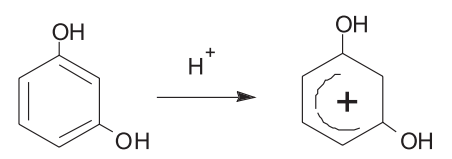

Table 1. Time period, induction period, frequency, amplitude and number of oscillations of the systems containing $\left[\mathrm{Mn}^{2+}\right]=\left[\mathrm{Ce}^{3+}\right]=\left[\mathrm{Ce}^{4+}\right]=$ $\left[\mathrm{Fe}^{2+}\right]=4 \times 10^{-3} \mathrm{~mol} \mathrm{~L}^{-1}$, [Resorcinol $]=0.0225 \mathrm{~mol} \mathrm{~L}^{-1},\left[\mathrm{BrO}_{3}^{-}\right]=$ $0.1 \mathrm{~mol} \mathrm{~L}^{-1}$, Temperature $=30 \pm 0.1^{\circ} \mathrm{C}$

\begin{tabular}{lccccc}
\hline Catalyst & $\begin{array}{c}\text { Induction } \\
\text { period } \\
\mathrm{t}_{\mathrm{in}} / \mathrm{s}\end{array}$ & $\begin{array}{c}\text { time } \\
\text { period } \\
\mathrm{t}_{\mathrm{p}} / \mathrm{s}\end{array}$ & $\begin{array}{c}\text { Frequency } \\
\mathrm{V} / \mathrm{s}^{-1}\end{array}$ & $\begin{array}{c}\text { Amplitude/ } \\
\mathrm{mV}\end{array}$ & $\begin{array}{c}\text { No. of } \\
\text { Oscillations }\end{array}$ \\
\hline $\mathrm{Mn}^{2+}$ & 130 & 67.5 & 0.0148 & 65 & $>40$ \\
$\mathrm{Ce}^{3+}$ & 350 & 460.0 & 0.0022 & 40 & $>10$ \\
$\mathrm{Ce}^{4+}$ & 170 & 95.5 & 0.0105 & 46 & $>25$ \\
$\mathrm{Fe}^{2+}$ & 600 & 470.5 & 0.0021 & 20 & $>7$ \\
\hline
\end{tabular}

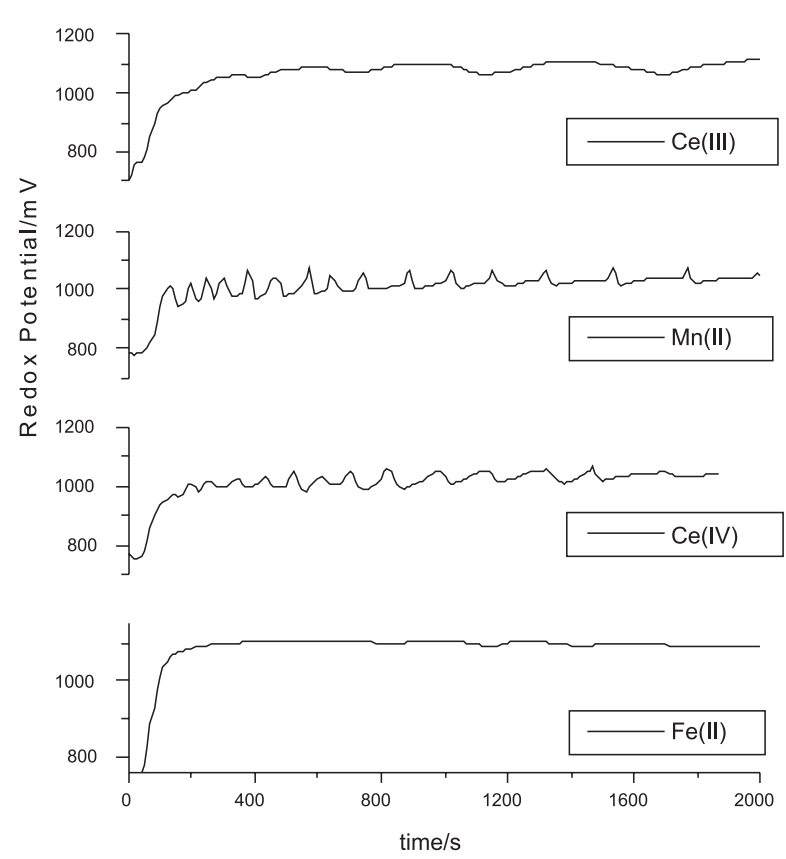

Figure 1. Potential versus time plots for the systems containing $[\mathrm{Ce}(\mathrm{III})]=[\mathrm{Ce}(\mathrm{IV})]=[\mathrm{Mn}(\mathrm{II})]=[\mathrm{Fe}(\mathrm{II})]=4 \times 10^{-3} \mathrm{~mol} \mathrm{~L}^{-1},\left[\mathrm{BrO}_{3}^{-}\right]=$ $0.1 \mathrm{~mol} \mathrm{~L}^{-1},[$ Resorcinol $]=0.0225 \mathrm{~mol} \mathrm{~L}^{-1}$ at $30 \pm 0.1^{\circ} \mathrm{C}$.

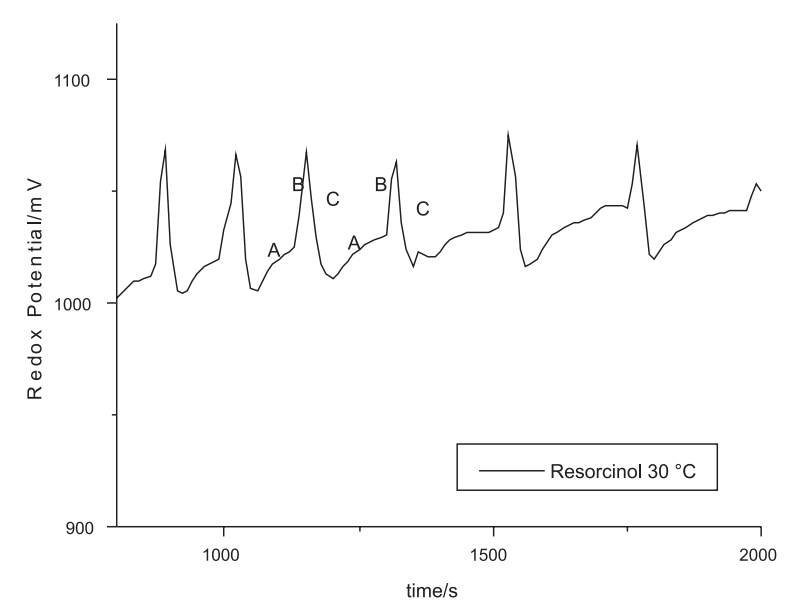

Figure 2. Potential versus time plot of the system containing $[\mathrm{Mn}(\mathrm{II})]=$ $4 \times 10^{-3} \mathrm{~mol} \mathrm{~L}^{-1},\left[\mathrm{BrO}_{3}^{-}\right]=0.1 \mathrm{~mol} \mathrm{~L}^{-1}$, [Resorcinol $]=0.0225 \mathrm{~mol} \mathrm{~L}^{-1}$ at $30 \pm 0.1^{\circ} \mathrm{C}$ (depicting processes $\mathrm{A}, \mathrm{B}$ and $\mathrm{C}$ ). 
The reactive protonated intermediate acts as a good nucleophile for bromide ion to form bromoderivatives.

Table 2 gives a comparative trend of oscillatory parameters with different aqueous acid media like sulfuric acid, nitric acid, orthophosphoric acid and perchloric acid. In perchloric acid protonation occurs at higher concentration, whereas in nitric acid, oscillations are seen with larger values of $t_{i n}$ and $t_{p}$. On the other hand sulfuric acid gives a good number of oscillations at lower as well as higher concentrations and the system is not reactive at all in orthophosphoric acid. Complex (mixed mode) type of oscillations are observed in $1.0 \mathrm{~mol} \mathrm{~L}^{-1}$ sulfuric acid medium (Figure 3), having a combination of large and small amplitude peaks. Mixed mode $\mathrm{e}^{40,41}$ type of oscillations is perhaps the most commonly occurring form of complex oscillations in chemical systems. The discovery of complex periodic behavior in such systems provides important support to the notion that chemical chaos is a phenomenon of some generality. It is noteworthy to mention that well pronounced results were obtained in $1.3 \mathrm{~mol} \mathrm{~L}^{-1} \mathrm{H}_{2} \mathrm{SO}_{4}$, as the reaction medium, while as in $1.0 \mathrm{~mol} \mathrm{~L}^{-1} \mathrm{H}_{2} \mathrm{SO}_{4}$, mixed mode oscillations with small and large peak amplitudes were observed. The oscillations observed exhibit patterns of the type $\mathrm{LS}_{\mathrm{n}}$, where $\mathrm{L}$ denotes oscillations with large amplitudes and $\mathrm{S}$ means oscillations with substantially small amplitudes as compared to $\mathrm{L}$, and $\mathrm{n}=0,1,2, \ldots$ In this system $n=1$, so we can have only one small amplitude oscillation between two larger amplitude oscillations. Such behavior of periodic mixed mode oscillations can be explained by considering the models ${ }^{42,43}$ that qualitatively describe regularities observed in transients as well as asymptotic mixed mode oscillations in the $\mathrm{BZ}$ reaction. The variables can be treated as autocatalytic reagent i.e., $\mathrm{HBrO}_{2}, \mathrm{Br}^{-}$which is involved in negative feedback, $\left[\mathrm{Mn}^{2+}\right]$ and concentration of acid i.e., $\left[\mathrm{H}^{+}\right] .{ }^{44}$

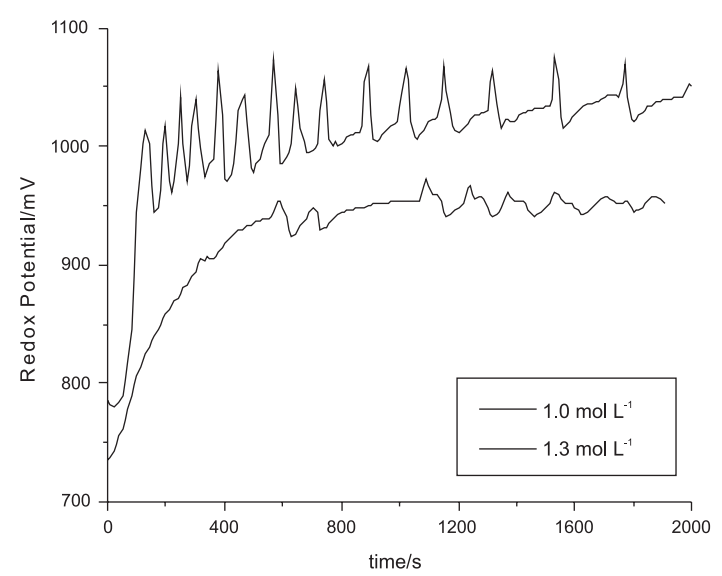

Figure 3. Comparative potential versus time plots showing mixed mode oscillations for $1.0 \mathrm{~mol} \mathrm{~L}^{-1} \mathrm{H}_{2} \mathrm{SO}_{4}$ (lower plot) and $1.3 \mathrm{~mol} \mathrm{~L}^{-1} \mathrm{H}_{2} \mathrm{SO}_{4}$ (upper plot), $[$ Resorcinol $]=0.0225 \mathrm{~mol} \mathrm{~L}^{-1},\left[\mathrm{BrO}_{3}^{-}\right]=0.1 \mathrm{~mol} \mathrm{~L}^{-1}$, $\left[\mathrm{Mn}^{2+}\right]=4 \times 10^{-3} \mathrm{~mol} \mathrm{~L}^{-1}$.
Table 2. Trends in the oscillatory parameters in different aqueous acid media having a range of concentrations

\begin{tabular}{lcccc}
\hline Acid & $\begin{array}{c}{[\text { Acid } /} \\
\left(\mathrm{mol} \mathrm{L}^{-1}\right)\end{array}$ & $\begin{array}{c}\text { No. of } \\
\text { oscillations }\end{array}$ & $\begin{array}{c}\text { time } \\
\text { period/s }\end{array}$ & $\begin{array}{c}\text { Induction } \\
\text { period/s }\end{array}$ \\
\hline & 0.5 & - & - & - \\
$\mathrm{H}_{2} \mathrm{SO}_{4}$ & 0.8 & - & - & - \\
& 1.0 & $>10$ & 300.0 & 330 \\
& 1.3 & $>40$ & 67.5 & 130 \\
\hline & 1.8 & - & - & - \\
\hline $\mathrm{HNO}_{3}$ & 0.5 & - & - & - \\
& 0.8 & - & - & - \\
& 1.3 & - & - & - \\
$\mathrm{H}_{3} \mathrm{PO}_{4}$ & 1.8 & $>10$ & 170.0 & 420 \\
& 0.8 & - & - & - \\
& 1.3 & - & - & - \\
$\mathrm{HClO}_{4}$ & 1.8 & - & - & - \\
\hline & 0.8 & - & - & - \\
\hline & 1.8 & $>5$ & 480.0 & 1170 \\
& 2.5 & $>20$ & 115.0 & 340 \\
\hline
\end{tabular}

- No or minimal oscillations are seen.

Amongst the different metal ions, $\mathrm{Mn}^{2+}$ ion based reaction system gave better oscillations in $1.3 \mathrm{~mol} \mathrm{~L}^{-1}$ sulfuric acid. Thus, in order to monitor the optimal impact of the $\mathrm{Mn}^{2+}$ ion as catalyst vis-à-vis $\left[\mathrm{BrO}_{3}^{-}\right]$as the oxidant, the oscillatory parameters of the reaction system were studied at different concentrations of $\mathrm{Mn}^{2+}\left(4 \times 10^{-3} \mathrm{~mol} \mathrm{~L}^{-1}\right.$ to $\left.8 \times 10^{-3} \mathrm{~mol} \mathrm{~L}^{-1}\right)$ and $\mathrm{BrO}_{3}^{-}$ion $\left(0.05 \mathrm{~mol} \mathrm{~L}^{-1}\right.$ to $\left.0.20 \mathrm{~mol} \mathrm{~L}^{-1}\right)$. The data is reported in Table 3. It is found that doubling the $\left[\mathrm{BrO}_{3}^{-}\right]$from $0.05 \mathrm{~mol} \mathrm{~L}^{-1}$ to $0.1 \mathrm{~mol} \mathrm{~L}^{-1}$ causes increase in rate and hence decrease in time period, while as on increasing further the concentration from $0.1 \mathrm{~mol} \mathrm{~L}^{-1}$ to $0.2 \mathrm{~mol} \mathrm{~L}^{-1}$ decreases the rate of reaction. Similarly, in case of $\left[\mathrm{Mn}^{2+}\right]$ there is decrease in rate as well as number of oscillations with increasing $\left[\mathrm{Mn}^{2+}\right]$ to double its earlier concentration, keeping other parameters constant. Further doubling the concentrations of both $\left[\mathrm{BrO}_{3}^{-}\right]$and $\left[\mathrm{Mn}^{2+}\right]$ gives no oscillations, as the concentration limit is approached. From this trend the effective concentration range where oscillations are seen is $0.05 \mathrm{~mol} \mathrm{~L}^{-1}$ to $0.20 \mathrm{~mol} \mathrm{~L}^{-1}$ for $\left[\mathrm{BrO}_{3}^{-}\right]$and $4 \times 10^{-3} \mathrm{~mol} \mathrm{~L}^{-1}$ to $8 \times 10^{-3} \mathrm{~mol} \mathrm{~L}^{-1}$ for $\left[\mathrm{Mn}^{2+}\right]$. Here we have seen that increase in concentration of bromate causes an increase in the reaction between resorcinol and bromate and there are lesser chances of negative feedback caused by the critical bromide ion concentration. Therefore, a few or no oscillations are seen. Same is the case with metal ion concentration.

In order to study the co-ion effect on the oscillatory behavior of resorcinol in $\mathrm{BZ}$ reaction, three salts of $\mathrm{Mn}$ (II) 
Table 3. Effect of $\left[\mathrm{Mn}^{2+}\right]$ and $\left[\mathrm{BrO}_{3}^{-}\right]$on the oscillatory parameters of the systems containing [Resorcinol] $=0.0225 \mathrm{~mol} \mathrm{~L}^{-1}$ at $30 \pm 0.1^{\circ} \mathrm{C}$

\begin{tabular}{lccc}
\hline $\begin{array}{l}{\left[\mathrm{BrO}_{3}^{-}\right] /} \\
\left(\mathrm{mol} \mathrm{L}^{-1}\right)\end{array}$ & $\begin{array}{c}{\left[\mathrm{Mn}^{2+}\right] /} \\
\left(\mathrm{mol} \mathrm{L}^{-1}\right)\end{array}$ & $\begin{array}{c}\text { time } \\
\text { period / s }\end{array}$ & $\begin{array}{c}\text { No. of } \\
\text { Oscillations }\end{array}$ \\
\hline 0.05 & 0.004 & 110.0 & 11 \\
0.1 & 0.004 & 67.5 & $>40$ \\
0.1 & 0.008 & 80.0 & $>1$ \\
0.2 & 0.008 & - & - \\
0.2 & 0.004 & 77.0 & 5 \\
0.1 & 0.005 & 80.0 & 9 \\
\hline
\end{tabular}

- No oscillation is seen.

ion with different co-ions like acetate, carbonate and sulfate were used in the reaction system, giving quite fascinating results (Table 4). Kinetically the rate of reaction with respect to $\mathrm{Mn}$ (II) sulfate is faster than the $\mathrm{Mn}$ (II) acetate which in turn is faster than $\mathrm{Mn}(\mathrm{II})$ carbonate. This could be due to the difference in the release of metal ions in these salts. We have exploited this type of behavior in these salts in order to study the effect of their anions as co-substrates in the $\mathrm{BZ}$ reaction. As such, the trend of these anions with respect to oscillatory parameters is as follows:

Sulfate $<$ acetate $<$ carbonate (with respect to $t_{\mathrm{p}}$ ) and carbonate $<$ acetate $<$ sulfate (with respect to $t_{\text {in }}$ )

However the trend for $t_{\text {in }}$ is opposite to $t_{p}$, owing to the involvement of the co-ions in the bromination of the substrate, wherein accumulation of bromoderivative to crucial concentration needs induction period. Despite the opposite trend exhibited with respect to $t_{\mathrm{p}}$ and $\mathrm{t}_{\mathrm{in}}$ values, the amplitude establishes the fact that the change in [Mn(III)]/ [Mn(II)] ratio is larger for Mn(II) sulfate followed by $\mathrm{Mn}$ (II) acetate, which in turn is followed by $\mathrm{Mn}$ (II) carbonate. Hence, aforesaid processes A, B and C are influenced by the presence of different co-ions (anions) with respect to same catalyst. However the only use of such salts with bromate without the use of resorcinol did not show oscillations, which serves as testimony to the fact that these anions play their

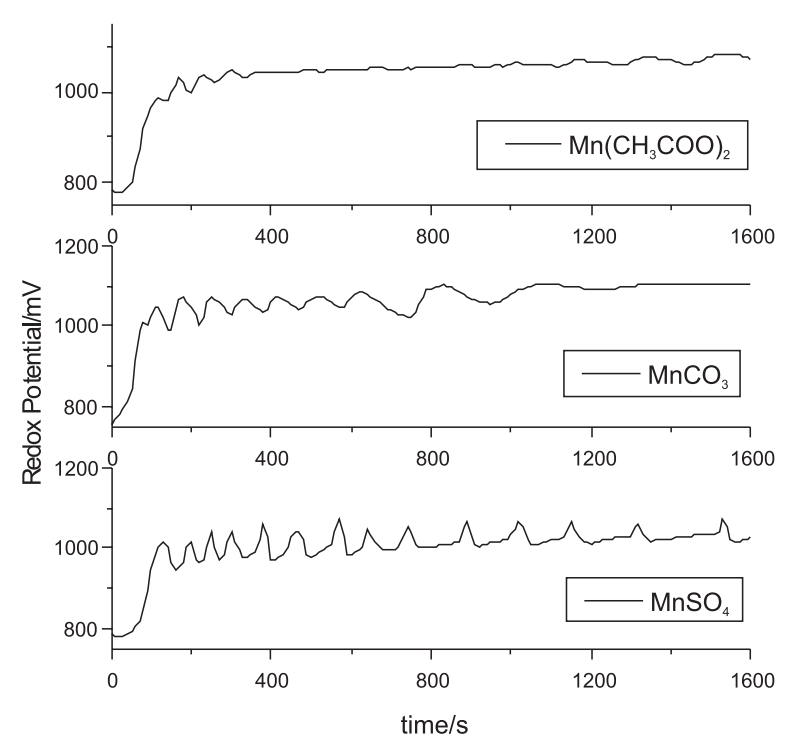

Figure 4. Potential versus time plots for the systems containing different salts of same metal ion with $[\mathrm{Mn}(\mathrm{II})]=4 \times 10^{-3} \mathrm{~mol} \mathrm{~L}^{-1},\left[\mathrm{BrO}_{3}^{-}\right]=0.1 \mathrm{~mol} \mathrm{~L}^{-1}$, $[$ Resorcinol $]=0.0225 \mathrm{~mol} \mathrm{~L}^{-1}$ at $30 \pm 0.1^{\circ} \mathrm{C}$.

role as co-substrates only and synergistically with the metal ion, which of course, serves as catalyst.

\section{Conclusions}

Resorcinol responded very well as the BZ oscillator in aqueous acid media. Amongst different metal ions, the oscillatory characteristics are much more pronounced with $\mathrm{Mn}$ (II) ion as catalyst. The reaction system showed good number of oscillations both at lower and higher concentrations of aqueous sulfuric acid as medium. Moreover, the anions of the same metal $\left(\mathrm{Mn}^{2+}\right)$ influences the oscillatory characteristics which adds new dimensions in $\mathrm{BZ}$ reaction with respect to mechanism and kinetics of such reactions.

\section{Acknowledgments}

The authors are thankful to CSIR, New Delhi for providing financial support. The authors also thank Head, Department of Chemistry, University of Kashmir, Srinagar for providing infrastructure and moral support to undertake the investigation.

Table 4. Time period, induction period, frequency, amplitude and number of oscillations of the systems containing the $\left[\mathrm{Salt}^{\mathrm{a}}\right]=4 \times 10^{-3} \mathrm{~mol} \mathrm{~L}^{-1},\left[\mathrm{BrO}_{3}^{-}\right]=$ $0.1 \mathrm{~mol} \mathrm{~L}^{-1}$, [Resorcinol $]=0.0225 \mathrm{~mol} \mathrm{~L}^{-1}$ at $30 \pm 0.1^{\circ} \mathrm{C}$

\begin{tabular}{lccccc}
\hline Salt & Induction period $\mathrm{t}_{\mathrm{in}} / \mathrm{s}$ & time period $\mathrm{t}_{\mathrm{p}} / \mathrm{s}$ & Frequency v/s ${ }^{-1}$ & Amplitude/ mV & No. of Oscillations \\
\hline Mn(II) acetate & 110 & 87.5 & 0.0114 & 50 & $>25$ \\
Mn(II) sulfate & 130 & 67.5 & 0.0148 & 65 & $>40$ \\
Mn(II) carbonate & 80 & 95.0 & 0.0105 & 35 & $>33$ \\
\hline
\end{tabular}




\section{References}

1. Nicolis, G.; Prigogine, I.; Self-Organization in Nonequilibrium Systems, Wiley: New York, 1977.

2. Zhabotinsky, A. M.; Biofizika 1964, 9, 306.

3. Zhabotinsky, A. M.; Chaos 1991, 1, 379.

4. Belousov B. P. In Oscillations and Traveling Waves in Chemical Systems; Field, R. J.; Burger, M., eds.; Wiley: New York, 1985, p. 605.

5. Field, R. J.; Burger, M.; Oscillations and Traveling Waves in Chemical Systems, Wiley: New York, 1985.

6. Epstein, I. R.; Showalter, K.; J. Phys. Chem. 1996, 100, 13132.

7. Epstein, I. R.; Pojman, J. A.; An Introduction to Nonlinear Chemical Dynamics: Oscillations, Waves, Patterns, and Chaos; Oxford University Press: New York, 1998.

8. Taylor, A. F.; Prog. React. Kinet. Mech.. 2002, 27, 247.

9. Vavilin, V. A.; Zhabotinsky, A. M.; Zaikin, A. N.; J. Phys. Chem. 1968, 42, 3091.

10. Vavilin, V. A.; Zaikin, A. N.; Kinet. Catal. 1971, 12, 309.

11. Field, R. J.; Koros, E.; Noyes, R. M.; J. Am. Chem. Soc. 1972, 94, 8649

12. Gyorgyi, L.; Turanyi, T.; Field, R.J.; J. Phys. Chem. 1990, 94 , 7162.

13. Gyorgyi, L.; Turanyi, T.; Field, R. J.; J. Phys. Chem. 1993, 97 , 1931.

14. Hegedius, L.; Wittmann, M.; Noszticzius, Z.; Yan, S.; Sirimungkala, A.; Forsterling, H. D.; Field, R. J.; Faraday Discuss. 2001, 120, 21.

15. Field, R. J.; Boyd, P. M.; J. Phys. Chem. 1985, 89, 3707.

16. Basavaraja, C.; Kulkarni, V. R.; Mohan, S.; Iyer, I. M.; Subba Rao, G. V.; Indian J. Chem., Sect. A: Inorg., Bio-inorg., Phys., Theor. Anal. Chem. 2004, 43, 739.

17. Blagojevic, S.; Pejic, N.; Anic, S.; Anic, L. K. J. Serb. Chem. Soc. 2000, 65, 709.

18. Field, R. J.; Burger, M.; Oscillations and Traveling Waves in Chemical Systems, Wiley: New York, 1985; p. 605.

19. Lone, M. A.; Nath, M. A.; Ganaie, N. B.; Peerzada, G. M.; Indian J. Chem., Sect. A: Inorg., Bio-inorg., Phys., Theor. Anal. Chem. 2008, 47, 705 .
20. Rastogi, R. P.; Chand, P.; Pandey, M. K.; Das, M.; J. Phys. Chem. A 2005, 109, 4562.

21. Harati, M.; Wang, J.; J. Phys. Chem. A 2008, 112, 4241.

22. Shin, S. B.; Choe, S. J.; Huh, D. S.; Bull. Korean Chem. Soc. 2000, 21, 215.

23. Pojman, J. A.; Dedeaux, H.; Forlenberry, D.; J. Phys. Chem. 1992, 96, 7331.

24. Koros, E.; Nature 1974, 251, 703.

25. Blandamer; Roberts, D. L.; J. Chem. Soc., Faraday Trans. I 1977, 73, 1056.

26. Yoshikawa, K.; Bull. Chem. Soc. Jpn. 1982, 55, 2042.

27. Fujieda, S.; Kawahito, J.; Thermochim. Acta 1992, $210,1$.

28. Rouff, P.; Physica D 1995, 84, 204.

29. Koros, E.; Burger, M.; Friedrich, V.; Landanyi, L.; Nagy, Z.; Orban, M.; Faraday Symp. Chem. Soc. 1974, 9, 28.

30. Tanimora, A.; Tsukada, M.; Juntedo Igaku 1997, 42, S37.

31. Rejman, J.; Kozubek, A.; Z. Naturforsch., C: Biosci. 2004, 59, 393.

32. Kozubek, A.; Demel, R. A.; Biochim. Biophys. Acta 1980, 603, 220.

33. Kozubek, A.; Acta Biochim. Pol. 1987, 34, 387.

34. Bitkov, V. V.; Neneshev, V. A.; Pridachina, N. N.; Batrakov, S. G.; Biochim. Biophys. Acta 1992, 1108, 224.

35. Kozubek, A.; Acta Biochim. Pol. 1995, 42, 247.

36. Field, R. J.; Noyes, R. M.; J. Chem. Phys. 1974, 60, 1877.

37. Tyson, J. J.; J. Chem. Phys. 1977, 66, 905.

38. Tyson, J. J.; Ann. N.Y. Acad. Sci. 1979, 316, 279.

39. Tyson, J. J.; Oscillations and Traveling Waves in Chemical Systems, Field, R. J.; Burger M., eds., Wiley: New York, 1985, p. 93.

40. Rossler, O. E.; Z. Naturforsch., A: Phys. Sci. 1976, 31, 259.

41. Barkley, D.; J. Chem. Phys. 1988, 89, 5547.

42. Rachwalska, M.; Kawczynski, A. L.; J. Phys. Chem. 1997, 101, 1518.

43. Strizhak, P. E.; Kawczynski, A. L.; J. Phys. Chem. 1995, 99 , 10830.

44. Rachwalska, M.; Kawczynski, A. L.; J. Phys. Chem. A. 1999, 103, 3455 .

Received: September 16, 2008 Web Release Date: May 29, 2009 